\title{
The Impact of the IAS/IFRS Adoption on the Predictive Quality of Discretionary Accruals: A Comparison between the French and the British Context
}

\author{
Ben Jemâa Olfa ${ }^{1}$ \& Mattoussi Hamadi ${ }^{2}$ \\ ${ }^{1}$ Higher Institute of Commerce and Accounting of Bizerte, University of Carthage, Tunisia \\ ${ }^{2}$ Higher Institute of Accounting and Company Administration University of Manouba, Tunisia \\ Correspondence: Ben Jemâa Olfa, Higher Institute of Commerce and Accounting of Bizerte, University of \\ Carthage, Tunisia. Tel: 216-9781-7779. E-mail: olfabenjemaa@yahoo.com
}

Received: February 20, 2015

Accepted: March 25, 2015

Online Published: May 25, 2015

doi:10.5539/ijef.v7n6p208

URL: http://dx.doi.org/10.5539/ijef.v7n6p208

\begin{abstract}
The purpose of this article is to study and compare the impact of the adoption of the international standards IAS/IFRS and the legal regime of a country on the pertinence of the discretionary accruals in terms of its quality of the prediction of future operating cash flows in two contexts: The French and United-Kingdom. The findings of our study prove that the adoption of these norms has clearly improved the predictive quality of discretionary accruals in the British context. In France, such effect has been demonstrated as significant and positive for both periods. The study of the impact of the IFRS norms on the predictive quality of discretionary accruals on the two European countries of our study shows that in the British context, the association between the discretionary accruals and the future operating cash flows is more important for the companies using the international norms than in those applying the British ones. In the French context, no significant association between the discretionary accruals and the IFRS has been verified. Next, our study has spread to see the impact of the legal regime on the predictive power of discretionary accruals before and after the adoption of the IAS/IFRS norms. The findings prove that the fullness of the association between the future operating cash flows and the discretionary accruals is stronger for the enterprises which are under the British context than those under the French one.
\end{abstract}

Keywords: discretionary accruals, relevance, IAS/IFRS, legal system, future operating cash-flows, French and British context

\section{Introduction}

Politics and capital market generalization all over the world has made the integration of principles and practices of financial divulge unavoidable (Ball, 2006; Burns, 2000). It is with an increase internationalization of both economic exchanges and business universality that the financial information, which is prepared with reference to the national accounting systems, could no more satisfy the needs of users whose decisions are more and more international (Zeghal \& Mhedhbi, 2012). Being conscious of this harmonizing necessity, the efforts of normalizing are accentuated to achieve this objective and it is the year 1973 which noticed the creation of the private organism I.A.S.C ( International Accounting Standard Committee). The main objectives of this organism are the following : to establish internationally acceptable accounting standards, to promote their use, and to work in order to harmonize the accounting laws and the presentation of the financial states at the international level. Since (2001), the I.A.S.B has modified its structure and its label to become The International Accounting Standard Board (I.A.S.B). During this reform, it has been decided that the norms and their interpretations would be henceforth relative not only to the process of accounting normalization but also to the financial news in general.

The tendency of accounting globalization has been on the one hand, accelerated by the voluntary accessory with IFRS (Note 1) norms; and on the other, reinforced by some other events which occurred in numerous countries during the late 1980's. Indeed, in November 1995, The European Committee (EC) emphasized that "The necessity for the European Union to react without delay so that those who prepare and those who use the account would have the securities that the companies, willing to place their capitals in the American market and 
on the other world markets, would not have to go outside the accounting framework of the Union." In 2000, The International Organization of Security Commission (I.O.S.C) recommended the I.A.S.C principles to those who intervene on the capital markets. In 2001, many capital markets all over the world to name: London, Frankfurt, Zurich, Luxemburg, Bangkok, Hong Kong, Amsterdam, and Rome, which accepted the financial states of the foreign firms quoted, have to be prepared according to the IFRS without any reconciliation. The European Commission and the Australian legislation announced that the IFRS would have to be adopted since 2005.

The compulsory adoption of these norms by the European Union countries and the formal commitment by the FASB and The I.A.S.B to converge the US GAAP to the international standards have clearly contributed to their wide acceptance by many countries all over the world (Ding et al., 2007). However, many researchers claim that the effects of this adoption may differ from one country to another (Flower, 1997; Zeff, 1998). In fact, as pointed out by (Ball, 2001; Hope, 2003; Hope et al., 2006), the accounting principles are present in mosaic in the frame of a complex institutional context and non in isolation. The modification of one piece of it would not be the best solution if the other institutional factors remain stable. On the same footing, Ball (2001) gives arguments that the mere modification of an accounting principle, without making the corresponding improvement at the level of law making and the development of capital markets, will lead nowhere as far as the financial disclosure of quality is concerned.

According to Soderstrom and Sun (2007), the conversion to IFRS seems to affect the financial disclosure but it is only one of the determining accounting quality factors. Other factors as the political and legal system of a country and the incitation of financial disclosure remain always determinant. The financial statements, which are considered as the most interesting means of communication between the enterprise and the investors, contribute generally to achieve an informational equilibrium between these two last and the decision-takers. In order to elaborate these files of synthesis, the managers are invited to make some estimations and judgments based on the interpretation of transactions and to choose through the practices and the accounting methods to adopt. Nevertheless, Peluci-Grecco et al. (2014), suggested in this case, that managers could make use of the flexibility of the accounting principles to maximize their wealth at the expense of the investors.

The manipulation of earnings constitutes one illustration of these opportunistic behaviors (Jones, 1991; Dechow et al., 1995; Kang \& Sivaramakrishnan, 1995; Teoch et al., 1998; Dechow \& Dichev, 2002; Kothari et al., 2005; Ball \& Shivakumar, 2008; Ghosh \& Olsen, 2009) this can happen when managers manipulate the accounting findings in order to reach or overcome those anticipated by financial analyzers Badertsher et al. (2012).

In practice, there are many mechanisms that can limit this doing such as: the accounting legislations, independent audit and the good practice of enterprises which are governing (Peluci-Grecco et al., 2014). The accounting laws, essentially those made by lawful organism of capital markets, could be a means to restrict the findings manipulations. The main objective of these laws is to guarantee comparison, transparency and the good quality of the news linked not only to the financial situation but also to the firm performance. Consequently, the more efficient the law, the less the manipulation (by the managers) is possible and thus a higher accounting quality data is produced. Therefore, every modification of a quality accounting law has as a consequence on the improvement of the accounting information quality and as a result the shrinking of the manipulation (by managers). Moreover, the outspread of the decision-takers opportunistic manipulations seem to be more significant in a high asymmetric context. Furthermore, the opportunistic manipulation of findings may increase uncertainty towards future cash flow, which will create on its turn, asymmetric information in the capital markets.

In this article, we suggest to examine the impact of the IAS/IFRS norms on the discretionary accruals pertinence to forcast the future operating cash flows in the British and the French context. Indeed, as suggested by Subramanyam (1996) and Krishnan (2003), on the contrary of other accounting earnings components, the discretionary accruals are more subjective and reflect a high level of managerial judgments. They allow managers to communicate their favorite and private data; and consequently, to improve the earnings capacity that reflect the economic value of the firm. Based on the findings of many researches which prove that there is a positive link between every element which has an important effect on the quality of the accounting data and the informative content of discretionary accruals. We suppose that the accounting norms of high quality increase the credibility of discretionary accruals in minimizing the opportunistic part and therefore, improve their informative content for the prediction of cash flow of future exploitation. It is in this framework that Ball (2001) noted that norms "of good" quality should protect the users of the transmitted accounting information in restricting the managers opportunistic accounting choices towards results managements.

The IAS/IFRS standards are generally considered more rigorous and detailed than the domestic accounting 
standards which they replace. They allow participants, in the capital markets, to better estimate the quality of the findings (Cormier et al., 2011). Furthermore, it is commonly argued that the adoption of the IAS/IFRS will lead to the reduction of the informative asymmetry between the investors and the firms through the increase of the disclosure and the improvement of the communicated accounting information (Gul et al., 2003; Ghosh \& Olsen, 2009). France, being a civil law country whose accounting principles are largely influenced by the system of imposing, has chosen, as all the other members of the European Union, to adjust with the IAS/IFRS norms since the year 2005 .

In our study, we examine the problem of the informative content of discretionary accruals for the future operating cash flows by reference to the IAS/IFRS standards. We choose to tackle this issue by comparing the British context,which is emerging from an Anglo-Saxon model with the French context, issuing from an Euro -continental one.

To the best of our knowledge, this study is the first to investigate how IAS/IFRS affect the value relevance of discretionary accruals in terms of its ability to predict future operating cash-flows, for comparison between the French and the UK contexts.

The remainder of this article is organized as follows: section 2 presents the theoretical background and the development of research propositions. The method is described in section 3. Results are interpreted in section 4. Finally, section 5 provides a conclusion and discussion of potential implications.

\section{Literature Review and Hypothesis}

The importance given to the accruals concept, as a pertinent component of the accounting earnings, has been reinforced by the identification of the discretionary dimension of the accruals themselves. Subramanyan (1996) divide the findings into: first, cash flow of exploitation, second, non discretionary accruals and third, discretionary accruals. This author demonstrates that the discretionary accruals are related to the findings and to the cash flow of future exploitation. These results confirm the informative value of the discretionary accruals. In fact, as suggested by Krishnan (2009), as t opposed to the other elements of the findings, the discretionary accruals are more subjective and reflect a high degree of managerial judgments. These allow the decisionmakers to communicate both their favored and private information and consequently to improve the result capacity to reflect the economic value of the enterprise. Nevertheless, the decision-takers may overuse the allowed flexibility given by the accounting principles, which are generally accepted and carry out aggressive divulges of accruals that may alter the informative content of the published results.

There are three approaches which have been identified in the accounting literature dealing with the choices of the discretionary accountings and each of which has some implications for the prediction of future operating cash-flows of the enterprise.

The first is of an "informative perspective" one. This approach stipulates that the discretionary accounting choices are accomplished in order to reveal the private information of the decision-takers concerning the study of future trends of the enterprise. Thus, offering some accruals elements which are the best for predicting future cash flow for the enterprise. Such perspective is widely illustrated by the accounting literature (Holthausen \& Leftwich, 1983; Watts \& Zimmerman, 1990; Subramanyam, 1996; Demski, 1998; Degeorge et al., 1999; Arya et al., 2003; Kanagaretnam et al., 2004; Altamuro et al., 2005; Louis \& Robinson, 2005; Badertsher et al., 2012), who consider that according to this point of view. the managers make use of the elasticity that exists in the accounting principles generally admitted to ameliorate the pertinence and the feasibility of the published accounting information; and consequently increases the predictive usefulness and faithful representation.

The second approach is "opportunistic”. It considers that managers make some discretionary accounting choices in order to conceal the truth surrounding the economic performance to improve their wealth at the expense of the investors (Jensen, 2005; Teoh et al.,1998; Dechow \& Skinner, 2000; Beneish, 2001; Nelson et al., 2002; Hribar \& Jenkins, 2004; Revsine et al., 2005; Badertsher, 2011). Badertsher, Collins and Lys (2012) consider that this approach is an "opportunistic perspective" which look for operating the possibility that decision-takers experienced the accounting discretion in order to, reach or go beyond the reference results as the ones forecasted by financial analyzers. In this case, Badertsher et al. (2012) consider that both the pertinence and feasibility and consequently the usefulness of prediction and the faithful representation become of secondary considerations because that these accrual choices are made for opportunistic reasons. These authors added that the accounting choices motivated by opportunistic reasons are intended to reduce the predicative power of the results and of its components for future cash flow because of the intervention of the decision-takers in the accounting process, is in this case classified as opportunistic, whose objective is to induce or to incite a bias or a noise in the published data. 
The third explanation is of the discretionary accounting choices of decision-takers are contractual. According to Badertsher et al. (2012), the contractual explanations of the accounting choices are in most cases classified into two: the opportunistic contractual hypothesis and the efficient contractual hypothesis. As far as the first hypothesis is considered, the manipulation of the accounting results is of an opportunistic trend (Healy et al., 1987; Guidry et al., 1999; Holthausen et al., 1995; Dufond \& Jiambalvo, 1994; Sweeny, 1994). For the second hypothesis, which is classified as efficient contractual perspective of the discretionary accounting choices, implies that bosses on the one hand, make their choices essentially to minimize the contractual cost trough different contractual parties of the firm; on the other to, to maximize the value of the enterprise. However, as suggested by Watts and Zimmmerman (1990), it would be difficult to separate the opportunistic accounting choices (posterior) from the efficient accounting choices. In fact, the first one could represent a level of the second ones and the decision-takers are conscious in order to protect the prices. On this bases Badertsher et al. (2012) consider that classifying part of the efficient discretionary accounting choices as opportunistic, may diminish the predicative power of discretionary accruals for future cash-flows. They explain that the managerial intervention in the accounting process, generally, add to the published information some noise and/or some bias, which can on its turn have negative implication on the predicative capacity of the discretionary accruals.

These divergence as to motivations, (informational, opportunistic or contractual) for the discretionary accounting choice and their divergent implications for the relation between the accounting results and their components (cash flows, discretionary accruals, non discretionary accruals) and the cash flows of future exploitation represent the motivations of our first hypothesis. In fact, as proved by Zimmmerman (1996), the current level of discretionary accruals is associated with the future profitability of the firm. Moreover, based on the informational perspective of discretionary accruals, Badertsher et al. (2012) showed that the discretionary choices of motivated managers, by informational objectives, are useful for the prediction of cash flow of future exploitation. This is how we formulate our first hypothesis which is the following:

\section{H1: The discretionary accruals have a predictive power for the future operating cash flows.}

Although the effect of choices between accounting methods for certain level of principle is examined by the positive accounting research (Watts \& Zimmerman, 1990), little attention was given to the effects of the difference at the level of accounting principles at the international level. Furthermore, as advanced by Choi (1991), the research on the empirical consequences of differences at the level of rules for accounting gauge across countries remains a prudent question.

In this part of our study, we will try to describe the essential characteristic of the performance model of prediction in two countries having different characteristic in terms of law making concerning the financial disclosure and the capital markets. Most studies that we have investigated during the review of the literature, and those which have particularly, examined the relation between the institutional accounting factors and the characteristic of the earnings and cash flow predictions, are based essentially on the prediction made by the financial analysts (Basu et al., 1998; Hope, 2004; Hope \& Kang, 2005).

Hope (2004) advanced that the variations at the level of the environment of the financial disclosure may have multiple effects on the financial file users. Consulting the literature review allowed us to make census of four institutional dimensions through which researchers tried to test the impact of international accounting differences on the predictive power of accounting news to label: the outspread of accrual registration, (Basu et al., 1998; Hope, 2004), the degree of choice through accounting methods (Basu et al., 1998; Hope, 2004); the use of the notion of the right price (Basu et al., 1998; Hope, 2004); and the power of the put onto practice of the accounting principles (Basu et al., 1998; Hope, 2004).

On the basis of the behavioral assertion according to which the precision decreases with the complexity of the task, Ashbaugh and Pincus (2001) argued from a debate on the use of IAS vis-à-vis domestic principles, that the presence of an important number of accounting methods increase the complexity of the work assigned to analysts. It is in this framework, that Elliott and Philbrick (1990) demonstrate that the variation in the accounting methods can attack the precision of the prediction operated by the financial analysts. From these findings, Hope (2004) suggested that the move from one situation, where the choice through the accounting methods is lower than another one where many methods were offered to account for a given transaction, could make the prediction of results by analysts less precise. Furthermore, He added that it would be difficult for analysts to correct the differences at the level of accounting methods in time and space across the enterprises and consequently the increase of the uncertainty can make the prediction less precise than when only one method is used. Indeed, the findings in his study allow confirming such suggestions. In fact, He demonstrates that the choice through accounting methods is negatively linked with the precision of the prediction. 
These findings and these suggestions are contradictories, which were proved by Basu et al. (1998). These authors affirm that the impact of the choice through the accounting methods on the errors of prediction of earnings by the financial analysts depend on several factors. They explained that according to an efficient contractual perspective, the choice between the accounting methods is a means which gives permission to firms to transmit real and pertinent news about their present and future performance. Moreover, they advanced that if the accounting methods are known in advance, the precision of the prediction will be the same throughout all the companies that are using different methods. However, if the choice between the methods is limited, those which are permissible will be optimal for some and non for others. Consequently, the analysts' prediction errors will be in average higher than when there is no restriction in the choice. Basu et al. (1998) advance that one of the arguments contrary to the restriction in the choice of the accounting methods is to facilitate the comparison of the financial state in time (consistency) and in space (uniformity). The principle is that it will be a little bit difficult for analysts to correct the differences at the level of the accounting methods throughout the companies and through time. Therefore, the prediction becomes less precise than when only one method is allowed.

Another argument linked to the opportunist behavior of managers which is presented in opposition to this choice. Indeed, according to Basu et al. (1998), these managers choose between the methods which may maximize their wealth at the expense of other shareholders interests' and the shrinking of such a choice could shorten such a possibility. However, facing this argument, and based on the results demonstrated by Kim and Schroeder (1990), who signal that analysts seem to take into consideration the outline of the users interests' in order to foretell the accounting earnings, Basu et al. (1998) affirmed that the restriction in the choice of the accounting methods is not necessary to improve the prediction capacity of those who intervene in the market provided that, the choice of the methods had to disclose in advance.

The put into application of the accounting principles is another topic that attracted the attention of many researchers in the field of accounting. In fact, Hope (2003a) affirmed that the overspread with which the principles are applied and the operated violations are as important as the principles themselves. In the same direction, Kothari (2000) advance that the quality of financial news, is dependent on both the quality of accounting principles and on the making of law imposed by the put into vigor of these principles. Nevertheless, even though, academics and practitioners agree on the importance of the application of the accounting principles as a determining element of the disclosure on news quality, little attention has been paid to the study of the impact of this dimension at the international level. Hope $(2003,2004)$ explains that such weakness is due to the complexity linked to the measure of this factor across the countries.

During the last decade, an important number of organizations have been implicated in the improvement and harmonization of the application of the accounting principles all over the world. Their efforts have been considered as an essential element in the infrastructure of the financial disclosure. Few of these organizations could be mentioned, for example: The I.A.S.B; the I.O.S.C; the W.F.E. the World Bank; the I.M.F; the S.E.C; the I.F.A; the U.E. These organizations have expressed a view linked to the lack of a global mechanism for the application of these accounting principles in general and of the international accounting principle (I.A.P) in particular. With regard to this, we can mention as an example the opinion expressed by (I.C.AE.W, 2000) according to which "A mechanism of applying the accounting principles is found necessary to support the application of international accounting principles. One of the major risks which may face the reputation principles of the I.A.S.C is the bias that can touch the interpretation of these international principles by national agencies of the accounting law".

According to Hope (2004), the power of applying the accounting principles is multidimensional and has many forms in numerous countries. For instance, the SEC is considered as the main organism which controls the application of the accounting principles in the U.S.A; in other countries, it is the financial market which insures such application. Foster, (1986) advances that in most countries, it is the financial market and the making of law of the government which divide the responsibility elaboration, supervision, and the application of exigencies in terms of law making.

On the basis of these suggestions, Hope $(2003,2004)$ affirms that the power of applying the accounting principles constitutes a capacity for the managers to adhere to the accounting principles prescribed, and consequently, represents a security against the instances of deceit of the financial divulge. He adds that the existence of a powerful law for the application of a principle would normally present insurance in favor of the consistency of the adopted methods throughout time. Thus, decrease as a matter of fact, the complexity of the prediction. Ball (2001) considers that reducing the possibility of fraud, increases the credibility of financial reports and as a result, decrease the uncertainty concerning the accounting methods adopted, which lead to facilitating the prediction task. 
Subramanayam (1996) divides the accounting earnigs into three elements: operating cash flows, the non discretionary accruals and the discretionary accruals. He demonstrates that the three components are not only strongly appreciated by the capital market, but also linked to the future profitability of the company. Because of their nature, the discretionary accruals allow the managers to commit some opportunistic behavior in the intention of maximizing their personal profit at the expense of those of the firm. Other ulterior studies demonstrate that the predictive ability of the accruals to forecast the future profitability is attributed to the discretionary component (Xie, 2001; Chan et al., 2001). Subramanayam (1996) and Krishnan (2003) examine the eventual existence of a link between the quality of the audit and the valorization of discretionary accruals for the capital market and their impact on future profitability. They demonstrate that the association between discretionary accruals and the stock return is stronger for the audited firms by the Big six. Furthermore, they show that the managers use the discretionary accruals in order to communicate the private news concerning the future profitability. Moreover, they proved that the audited discretionary accruals by the Big six auditors have a superior predictive value to those audited by the non Big six cabinet. These authors interpreted that a high quality audit can reduce the aggressive and opportunistic manipulations of discretionary accruals.

Nevertheless, the harmonizing effort to reduce the disparity between the practices of financial disclosure and the adoption of international standards by many countries all over the world, exhorted numerous reactions in the international accounting environment, and different points of views have been expressed. In fact, the common European framework is marked by the presence of two big classes of the accounting models: Anglo -Saxon and the Euro- continental each of which has different characteristics in terms of the financial market and the orientation of the financial information.

The IFRS standards are characterized by their orientation towards the capital market and the excessive use of the concept "the fair value". In France, The European Union decision has faced many opponent reactions. According to Raffournier (2007), although the decision adopted by the IFRS could be applied to all the European Union countries, they do not seem to induce such opponents as in France. He said that the negative reactions are attributed to the deep change of the accounting philosophy that implies the adoption of the IFRS, and that it represents a true cultural cut and requires new competence on the part of accounting practitioners.

As far as the Anglo-Saxon orientation countries are concerned, whose adoption does not seem to incite the same critics. Indeed, the IFRS as advanced by Capron and Chiapello (2005), are the representatives of the Anglo-Saxon conception. According to these standards, the accounting information has to favor the financial and economic analysis which was central in the training program of the Anglo-Saxon countries; but it was not of the same importance given to the Euro-continental ones. In this sense, Raffournier (2007) develops that in waiting for the training program to progress the French accounts are in somehow handicapped compared to their homologue Anglo-Saxons, whose education, through time, has widely used the financial and economic analysis.

Examining the new quality linked to the discretionary accruals in an environment using the IAS/IFRS has become a topic which interests many recent researches. The impact of the IAS/IFRS standards at the level of the manipulation of the accounting results using the discretionary accruals has made the object of an important number of empirical verification and the results of these studies are various.

Ding et al. (2007) considered that the differences translated in terms of "absence" and of "divergence" between the domestic standards of a country and the international norms may have important implications on the disclosure quality. They demonstrated that a high score in terms "of absence" may create an important margin for the earnings manipulation and consequently, the firms which are in countries characterized by a non-sophisticated-accounting legislation have the tendency to achieve an advantage of accounting discretion linked to the manipulation of earnings. In the contrary, for the sign of "divergence" no significant link has been detected with the result manipulation.

Aussenegg et al. (2009) examined the impact of the adoption of the IAS/IFRS standards at the level of the accounting results manipulation in fifteens countries of the European Union. In this study, the IAS/IFRS standards have been integrated in the models as a mute variable. Tests have proved that the result manipulations seems to be lower in two regions of central Europe (German law countries: Austria, Germany, and, Switzerlandand three French law countries: Belgium, France and Netherland). Nevertheless, in the United Kingdom, Ireland and Northern European countries, which are characterized by a low level of results manipulations, no difference has been detected between the IFRS and domestic GAAP.

Christensen et al. (2008) studied that the impact of the IAS/IFRS standards on the earnings manipulation in the German context based on two categories of the firms. The first, those which adopt the voluntary standard, and the second, those which apply the obligatory way. They demonstrated that the second ones require less 
advantages of the IAS/IFRS standards. These opinions which prove that the positive impact of the voluntary adoption on the pertinence of the accounting news are divided by the studies of Soderstrom and Sun (2007) and Leuz and Wysoki (2008). Contrary to these opinions, Hung and Subramanyam (2007) didn't observe any positive association between the voluntary adoption of the IAS/IFRS standards and the pertinence of the accounting news in the German context. These same conclusions were deduced by Eccer and Healey (2003), who compared the accounting news published with reference to the Chinese standards.

As a reaction to these results, Christensen et al. (2009) suggested that the companies, which adopted the IFRS voluntary, prove a better improvement in the liquidity of their shares and the capital cost. In fact, the obligatory assortment of the IFRS norms does not constitute a sufficient condition to the improvement of the financial disclosure; but rather other institutional and legislative factors prevail. In addition, as mentioned by Ball et al. (2003) it would be a little bit naif to say that the application of an identical level of an accounting principle will lead to the same level of financial disclosure. The economic environment of a country remains always significant. In order to justify these interpretations, many studies are reinforced to examine and explain the effect of the adoption of the IAS/IFRS standards in many contexts.

Li (2010) studied the impact of the transition towards IFRS standards in eighteen countries. They demonstrated that the reduction of the capital cost was only observed in the countries characterized by a strong legal enforcement. Daske et al. (2008), Bruggerman et al. (2009), and Li (2010) suggested that such a reduction in the informative asymmetric system between the decision-makers and investors result from the following. First, the high quality of the financial divulges. Second, an interesting follows up by a big number of financial analyzers. Third, a rigorous control of the application of international norms by auditors and directors. In the same frame, Horton and Serafeim (2007) demonstrate that in the British context, the enterprises, which publish results according to the IFRS inferior to the one determined by the British principles, are penalized by the financial market.

Always with reference to the British context, Christensen et al. (2009) demonstrate that the transition toward the international standard do not produce only to itself information about the future cash flow. This is because the capital market is highly developed regulated, dominated by the public financing system and that the British accounting principles quality is comparable to that of the IAS/IFRS standards. Nevertheless, they foretell that from the fact that the accounting news can affect the distribution of wealth between creditors and investors. The finding of the study proved that the reaction in the return of the shares to the reconciliation to IAS /IFRS and that it was detected in a more significant way near to enterprise having a high cost capital. According to Iatridis (2010), despite that the adoption of the IAS/IFRS norms has increased the level of the news available to investors in the British context; it has on the other side, created not only a higher uncertainty linked to the prediction of the accounting results by financial analyzers, but also some volatility at the level of the British result status due to the excessive use of the notion of the right value.

In the French context, Cormier et al. (2009) demonstrate that the first adoption of the IAS/IFRS by the French enterprises was perceived as of a sign of improvement in their financial status. Moreover, in a comparative study dealing with France, the United Kingdom, and Austria, Jean Jean and Stolowly (2008), demonstrate that the application of the IAS/IFRS standards did not have as an impact on the diminishing of the manipulation of results which on the contrary increased for France. These authors conclude that the application of a uniform level of accounting principles does not constitute a sufficient condition to create a common financial language. The incitation of decision-takers and the institutional factors remain always determinant characteristics of the financial divulge.

Based on a sample of composed of ninety six observations of French enterprise making part of the CAC40, Boumediane et al. (2014) examine the impact of the adoption of the IAS/IFRS standards on the manipulation of earnings. In this analysis, the authors choose two periods: one before adoption (2003-2004) and another one after adoption (2006-2007). The findings prove that the manipulation exists before and after the acceptance. However, the adoption of the international standards helped reducing this manipulation. Two explanations were presented in these findings. First, they considered that the transition to international standards represent a difficult stage which requires placing a new system of news, training of staffs, an understanding of the privilege and inconvenience of this passage. Consequently, there is some distrust and prudence on the part of the decisiontakers while applying these new accounting politics. Also, based on the anterior literature, (Nafti et al., 2013; Kothari et al., 2003; Mariam \& Jacque, 2007; Bartov, 2004; Aboody et al., 1999) these authors suggested that after the application of the IAS/IFRS norms, the managers are less incited to manipulate the earnings up because the put into place of the fair value notion will have as a consequence the immediate increase of the findings. 
On the basis of the findings of the studies synthesized above, the second hypothesis that comes is the following:

\section{H2: The international standards IAS/IFRS affect differently the predictive ability of the discretionary accruals in France and the UK.}

According to our observation of the studies linked to the debate on the effects of the IAS/IFRS, the empirical evidences such as mentioned above are mixed. Bogstrand and Larson (2012) suggested that the econometric considerations could be a possible explanation. In fact, the selective criteria of the sample and/ or the methodological choice such as the omission of some variables, the lack of robustness, and/ or the deflation problems through the firms of the sample could be a source of bias. Furthermore, the accounting literature linked to this part of research considers that it is rather the legal environment quality and institutional factors that govern the industries, the countries and regions, constitute the most persuasive explanation. Soderstrom, and Sun (2007) and Leuz and Wyoski (2008) consider that the institutional factors as the legislative accounting system and the protection degree of investors, are the extremely important elements in the making of the manner with which the companies and investors react to the financial disclosure. In reality, as explained by anterior researchers (Ball, Kothari, \& Robin, 2000; Leuz, Nanda, \& Wysocki, 2003), it is the national organism power of the accounting legislation which direct the interaction between investors and firms and will affect consequently the nature and the manner with which the companies communicate accounting in their financial reports. The argument presented by Bogstrand and Larson (2012) to these interpretations is that in some industries, some countries and some regions, the investors 'rights and other shareholders are found injured by the dealing of the managers whose choices are affected by their personal incitation non in conformity with the accounting legislative requirements which minimize therefore the accounting quality and the put into question the pertinence and the feasibility of financial reports.

The above interpretations allow us to represent initiations on the effects which the international norms could have on the quality of financial disclosure in general and on the pertinence of the accounting information in particular. Certainly, as developed in the anterior accounting research (La Porta et al., 2002; Genther \& Young, 2000; Haw et al., 2004; Leuz \& Wyosocki, 2008). A weak Institutional environment looks for the efficacy of the accounting principles. Consequently, the reduction of the accounting quality through financial reports, and to be prudent in the studies interested by the impact of the IAS/IFRS norms on the accounting information pertinence. These dissertations lead us to the development of the 3rd hypothesis:

\section{H3: The country's legal regime affects the predictive ability of discretionary accruals.}

\section{Research Methodology}

\subsection{The Sample of the Study}

Our sample is composed of firms quoted on the $S B F 120$ between 1990 and 2008 for the French firms. For the British companies, are those quoted on the FTSE 500 between 1998-2008.

The firms of our sample are part of all activities sectors, except the financial sector because of the particularities that it represents for both the legislative and specifities in terms of accounting treatment sides. Our French and British sample are classified in eight sectors of activities: agriculture, forests, fishing, mines sectors, manufactory, transport sector, communication electricity and gas, wholesale commerce, retail commerce sector, service sector.

The Table 1 presents British firms for the period before adoption, the number of enterprises is of 103 and 102 for the period after adoption. In fact, in terms of the data available, six enterprises of this first sample have been excluded and other five added during the period after adoption.

Table 2 presents the classification of French companies; they are among 62 current period before adoption. This number is 68 for the period after adoption that the first sample, one company was rejected given the unavailability of the information, and seven others have been added.

Table 1. Classification of British firms by activity sectors

\begin{tabular}{lccc}
\hline \multicolumn{4}{c}{ Sample for the period before adoption of IAS/IFRS } \\
\hline Sector of activity & $\begin{array}{c}\text { Number of } \\
\text { companies }\end{array}$ & $\begin{array}{l}\text { Number of observations } \\
\text { Companies -years }\end{array}$ & $\begin{array}{l}\text { Frequency within the } \\
\text { sample in \% }\end{array}$ \\
\hline Sector Agriculture, forestry, and fisheries & 6 & 36 & 5,8 \\
Sector Mining & 6 & 33 & 5,8 \\
Sector Construction & 12 & 66 & 11,7 \\
Sector Manufactures & 16 & 108 & 15,5 \\
\hline
\end{tabular}




\begin{tabular}{lccc}
\hline Sector Transportation and communication & 32 & 194 & 31,1 \\
Sector Wholesale & 2 & 13 & 2 \\
Sector Retail & 6 & 34 & 5,8 \\
Sector services & 23 & 132 & 22,3 \\
\hline Total & $\mathbf{1 0 3}$ & $\mathbf{1 0 0}$ \\
\hline & Sample for the period after adoption of IAS/IFRS & 5,88 \\
\hline Sector Agriculture, forestry, and fisheries & 6 & 29 & 5,88 \\
Sector Mining & 6 & 30 & 11,764 \\
Sector Construction & 12 & 57 & 16,666 \\
Sector Manufactures & 17 & 80 & 32,35 \\
Sector Transportation and communication & 33 & 159 & 1,96 \\
Sector Wholesale & 2 & 10 & 5,88 \\
Sector Retail & 6 & 30 & 19,61 \\
Sector services & 20 & 89 & $\mathbf{1 0 0}$ \\
\hline Total & $\mathbf{1 0 2}$ & $\mathbf{4 8 4}$ & \\
\hline
\end{tabular}

Table 2. Classification of French firms by activity sectors

\begin{tabular}{|c|c|c|c|}
\hline \multicolumn{4}{|c|}{ Sample for the period before adoption of IAS/IFRS } \\
\hline Sector of activity & $\begin{array}{l}\text { Number of } \\
\text { companies }\end{array}$ & $\begin{array}{l}\text { Number of observations } \\
\text { Companies -years }\end{array}$ & $\begin{array}{l}\text { Frequency within } \\
\text { the sample in \% }\end{array}$ \\
\hline Sector Mining & 3 & 14 & 4,84 \\
\hline Sector Construction & 4 & 24 & 6,45 \\
\hline Sector Manufactures & 15 & 89 & 24,2 \\
\hline Sector Transportation and communication & 22 & 127 & 35,48 \\
\hline Sector Wholesale & 2 & 12 & 3,23 \\
\hline Sector Retail & 4 & 24 & 6,45 \\
\hline Sector services & 12 & 70 & 19,35 \\
\hline Total & 62 & 360 & 100 \\
\hline \multicolumn{4}{|c|}{ Echantillon de la période après adoption des normes IAS/IFRS } \\
\hline Sector Mining & 4 & 18 & 5,8 \\
\hline Sector Construction & 6 & 28 & 8,8 \\
\hline Sector Manufactures & 18 & 83 & 26,47 \\
\hline Sector Transportation and communication & 21 & 91 & 30,88 \\
\hline Sector Wholesale & 2 & 8 & 2,9 \\
\hline Sector Retail & 4 & 20 & 5,8 \\
\hline Sector services & 13 & 63 & 19,12 \\
\hline Total & 68 & 311 & 100 \\
\hline
\end{tabular}

\subsection{Definition of Variables}

The accounting information is collected directly from the financial statements composed of the balance sheets, income statements and notes to the financial statements.

\subsubsection{Operating Cash-Flow}

In our research, it's operating cash-flows that are retained. According to paragraph 18 of the IAS7 norm, there are two methods to realize the exploitations activities: the direct method and the indirect one. In the first one, the information is supplied on the main categories of the ins and outs the raw bottom; whereas in the second, the liquidity resulting from the exploitation activities are obtained in adjusting the net benefice (or the net loss) of the operation not having a monetary character. Both using the direct and indirect methods are authorized for the presentation of cash flow of exploitation. In our study, this variable is directly extracted from the cash-flows statement.

\subsubsection{Discretionary Accruals}

Healy (1985) considers that the published earnings have two components: one constituted of charges and of products opening the path to ins and outs of treasury flow. The other, constitutes charges and products calculated and displaced (the accruals). The last component pick up that the application of the commitment accounting 
principle. It is composed of two variables: one non-discretionary and another one discretionary. The second component is disposed to the manager discretion from the fact that it is on the one side topic of flexibility in the application of accounting principles; and on the other side, to the professional judgment exercise. McNichols and Wilson (1988) emphasis that it is the discretionary accruals which constitute the base for the manipulation of earnings. Many models were suggested to determine the discretionary accruals (Jones, 1991; Subramanyam, 1996). Nevertheless, in order to estimate the discretionary accruals, it is convenient firstly to calculate the total accruals. Dechow, Sloan, and Sweeny (1995) supply evidence that the modified model of Jones has the highest power to detect the accounting result manipulation than the other competitive models. This model is formulated as follow:

$$
T A_{i, t} / A_{i, t-1}=\alpha_{1}\left(1 / A_{i, t-1}\right)+\alpha_{2} \alpha_{2}\left(\Delta R E V_{i, t}-\Delta R E C_{i, t} / A_{i, t-1}\right)+\alpha_{3}\left(P P E N_{i, t} / A_{i, t-1}\right)+\varepsilon_{i, t}
$$

With:

TAi,t: total accruals in period $t$ for firm I;

$\triangle \mathrm{REV}_{\mathrm{i}, \mathrm{t}}$ : change in turnover between $\mathrm{t}$ and $\mathrm{t}-1$ for firm $\mathrm{I}$;

$\triangle \mathrm{CRE}$ i,t: change in receivables from clients between $\mathrm{t}$ and $\mathrm{t}-1$ for firm I;

PPENi,t: net value of property, plant, and equipment scaled by lagged total assets of firm i in year t;

$\mathrm{A}_{\mathrm{i}, \mathrm{t}-1}$ : Total Assets at end of period t-1 for firm i.

$$
\varepsilon_{i, t}: \text { Error term }
$$

The discretionary accruals are determined by the difference between the total accruals (TA) and the non-discretionary accruals (NDA). Thus, the $T A$ is determined by the difference between the result before extraordinary elements and the cash-flows of exploitation.

$$
T A=\text { Net result before extraordinary elements - Operating cash-flows. }
$$

The non discretionary accruals (NDA) are determined by the predicted values for the model described above and the discretionary accruals (DA) corresponding to the terms of mistakes of the same model.

\subsection{Models of the Study}

In order to test the predictive quality of the discretionary accruals to forecast future operating cash-flows, the model formulated in this way is the following:

$$
C F_{i, t}=\beta_{0}+\beta_{1} C F O_{i, t-1}+\beta_{2} A D_{i, t-1}+\beta_{3} A N D_{i, t-1}+\varepsilon_{i, t} \text { (Model 1) }
$$

CFO: Operating cash-flows;

$A D$ : Discretionary accruals;

$A N D$ : Non Discretionary accruals.

In order to concretize the adoption impact of the international standards on the predictive ability of the accounting information and essentially on the predicative quality of discretionary accruals, we were based on the same steps to study the impact of accounting normalization nature on the predicative power of accounting information. The objective of this part is binary: it consists to study first the impact of the adoption of the IAS/IFRS in each case of the both countries of the European Union, GB and France and consequently if the impact of this adoption varies through both countries.

In this frame, based on the work of Subramanyam (1996) and Krishnan (2003) we have constructed a model which allows examining the influence of the adoption of international norms on the foresight of future profitability of the enterprise. Our model allows comparing the international referential to the accounting referential of the two countries. This model is presented as follow:

$$
C F O_{\mathrm{i}, \mathrm{t}+1}=\beta_{0}+\beta_{1} C F O_{\mathrm{i}, \mathrm{t}}+\beta_{2} A D_{\mathrm{i}, \mathrm{t}}+\beta_{3} A N D_{\mathrm{i}, \mathrm{t}}+\beta_{4} I F R S_{\mathrm{i}, \mathrm{t}}+\beta_{5} A D_{\mathrm{i}, \mathrm{t}} * I F R S_{\mathrm{i}, \mathrm{t}}+\varepsilon_{i, t} \text { (Model 2) }
$$

IFRS: 1 if the enterprises use the international accounting standards.

$\{0$ if the enterprises use the British and French accounting standards.

The third model tests the impact of the country's legal regime on the predictive quality of the discretionary accruals after the adoption of the IAS/IFRS norms in Great Britain and France. This is formulated as:

$$
C F O_{\mathrm{i}, \mathrm{t}+1}=\beta_{0}+\beta_{1} C F O_{\mathrm{i}, \mathrm{t}}+\beta_{2} A D_{\mathrm{i}, \mathrm{t}}+\beta_{3} A N D_{\mathrm{i}, \mathrm{t}}+\beta_{4} U K_{\mathrm{i}, \mathrm{t}}+\beta_{5} A D_{\mathrm{i}, \mathrm{t}} * U K_{\mathrm{i}, \mathrm{t}}+\varepsilon_{i, t} \text { (Model 3) }
$$

$U K:\{1$ if the enterprises are part of the British context.

$\{0$ if the enterprises are part of the French context. 


\section{The Study Findings}

\subsection{Descriptive Statistics}

The descriptive statistics presented in Table 3 reveals that the average of operating cash-flows is positive for both countries. Nevertheless, this average is negative for the French context the period before IAS/IFRS standards adoption. For the variation of operating cash-flows, it is more important in UK than in France. For the DA, the descriptive statistics shows that the average is negative for both countries during the period before adoption. Such average has become positive for both countries during the period after adoption. The variation of discretionary accruals is neatly more important in the UK than in France for the period before and after adoption. As far as the non-discretionary accruals are concerned, their average is negative during the period before adoption, whereas it is positive for the period after adoption. The variation of this variable is more important in UK than in France.

Table 3. Descriptive statistics earnings components

\begin{tabular}{|c|c|c|c|c|}
\hline \multicolumn{5}{|c|}{ The French } \\
\hline Panel A & Min & $\operatorname{Max}$ & Mean & Std dev \\
\hline \multicolumn{5}{|c|}{ French GAAP } \\
\hline CFO & -0.3424163 & 135.2928 & 4.264964 & 19.0325 \\
\hline AND & -113.0523 & 253.5435 & -0.0881839 & 11.38718 \\
\hline DA & -85.09541 & 32.17323 & -1.99397 & 16.38423 \\
\hline \multicolumn{5}{|c|}{ IFRS } \\
\hline CFO & -0.4983214 & 0.9644668 & 0.0916449 & 0.1094059 \\
\hline AND & -0.0265848 & 0.20772 & 0.0004427 & 0.0120252 \\
\hline DA & -0.0021571 & 0.0145848 & 0.000103 & 0.0012227 \\
\hline \multicolumn{5}{|c|}{ The UK } \\
\hline Panel B & Min & Max & Mean & Std dev \\
\hline \multicolumn{5}{|c|}{ UK GAAP } \\
\hline CFO & -3.515625 & 246.3086 & 2.407817 & 20.60231 \\
\hline NDA & -431.8692 & 253.5435 & -0.1874707 & 32.82959 \\
\hline DA & -10.26931 & 2.640912 & -4.102846 & 56.63279 \\
\hline \multicolumn{5}{|c|}{ IFRS } \\
\hline CFO & -851.9886 & 167.2443 & -2.143785 & 41.8004 \\
\hline NDA & -18.40417 & 16.44198 & 0.0699435 & 1.206878 \\
\hline DA & -16.44448 & 18.39792 & 0.000103 & 1.201339 \\
\hline
\end{tabular}

Note. CFO: Operating cash-flows; $\boldsymbol{A N D}$ : Non discretionary accruals ; $\boldsymbol{D} \boldsymbol{A}$ : Discretionary accruals.

From Table 4, the correlations of Pearson show that for the period before adoption the IAS/IFRS norms, the non-discretionary accruals components are significantly and negatively correlated with the cash-flow of exploitation for both European countries. Nevertheless, for Spearman's correlations, it is significant and negative between the cash-flow of exploitation and the non-discretionary accruals for both countries. On the contrary, it is significant and negative between the discretionary accruals and the cash-flow of exploitation for France and non-significant for the U.K. For the period after adoption, the Pearson's correlation between discretionary and non-discretionary and the cash-flow of exploitation do not show significance in both cases. Whereas, they prove significant and negative correlations between the non-discretionary accruals and the operating cash-flows in the two context. As for the discretionary accruals, their correlation with the operating cash-flows is negative and significant for France but non-significant for the UK. 
Table 4. The correlations of pearson (spearman) above (below) du diagonal

\begin{tabular}{|c|c|c|c|}
\hline \multicolumn{4}{|c|}{ Before IFRS } \\
\hline & CFO & AND & AD \\
\hline \multicolumn{4}{|c|}{ CFO } \\
\hline$U K$ & 1 & $-0,489 * *$ & $-0,600 * *$ \\
\hline$F R$ & 1 & $-0,769 * *$ & $-0,466^{* *}$ \\
\hline \multicolumn{4}{|l|}{ AND } \\
\hline$U K$ & $-0,123 * *$ & 1 & $0.406^{* *}$ \\
\hline$F R$ & $-0,218 * *$ & 1 & 0,083 \\
\hline \multicolumn{4}{|l|}{ AD } \\
\hline$U K$ & $-0,073$ & $-0,614 * *$ & 1 \\
\hline$F R$ & $-0,104 * *$ & $-0,750 * *$ & 1 \\
\hline \multicolumn{4}{|c|}{ After IFRS } \\
\hline & CFO & AND & AD \\
\hline \multicolumn{4}{|l|}{ CFO } \\
\hline$U K$ & 1 & $-0,029$ & 0,033 \\
\hline$F R$ & 1 & $-0,019$ & $-0,093$ \\
\hline \multicolumn{4}{|l|}{ AND } \\
\hline$U K$ & $-0,210 * *$ & 1 & $-0,699 * *$ \\
\hline$F R$ & $-0,200 * *$ & 1 & $0,387^{* *}$ \\
\hline \multicolumn{4}{|l|}{ AD } \\
\hline$U K$ & $-0,042$ & $-0,690 * *$ & 1 \\
\hline$F R$ & $-0,116^{*}$ & $-0,324 * *$ & 1 \\
\hline
\end{tabular}

Note. CFO: Operating cash-flows; AND: Non discretionary accruals; DA: Discretionary accruals; ${ }^{* * *}$ significant at the level of $1 \%$, ** significant at the level of $5 \%$, * significant at the level of $10 \%$.

\subsection{Multi-Varied Findings Analysis}

4.2.1 Discretionary Accrual Predicative Quality Analysis before the Adoption of the IAS/IFRS Standards

Table 5. Synthesis of statistics related to regression of future operating cash flows on past operating cash-flows and the component discretionary and non discretionary accruals

\begin{tabular}{|c|c|c|c|c|}
\hline \multicolumn{5}{|c|}{ 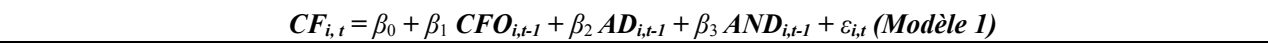 } \\
\hline \multirow{2}{*}{ Variable } & \multicolumn{2}{|c|}{ Grande Bretagne } & \multicolumn{2}{|c|}{ France } \\
\hline & Coef & P-value & Coef & P-value \\
\hline Constant & $-1,044$ & $(0,003)^{* * *}$ & 5,779 & $(0,000)^{* * *}$ \\
\hline$C F O_{t-1}$ & 0,5068 & $(0,000)^{* * *}$ & 0,2339 & $(0,018)^{* *}$ \\
\hline$A D_{t-1}$ & $-0,532$ & $(0,000)^{* * *}$ & 1,216 & $(0,000)^{* * *}$ \\
\hline$A N D_{t-1}$ & 0,192 & $(0,000) * * *$ & 0,158 & $(0,120)$ \\
\hline \multicolumn{5}{|c|}{ Tests de validité du modèle } \\
\hline \multicolumn{5}{|l|}{ Hausman test } \\
\hline Chi2 & \multicolumn{2}{|c|}{404,75} & \multicolumn{2}{|c|}{152,96} \\
\hline $\operatorname{Prob}>\operatorname{ch} 2$ & \multicolumn{2}{|c|}{$(0,0000)^{* * *}$} & \multicolumn{2}{|c|}{$(0,0000)^{* * *}$} \\
\hline \multicolumn{5}{|l|}{ test Breusch-Pagen } \\
\hline Chi2 & \multicolumn{2}{|c|}{1,16} & \multicolumn{2}{|c|}{9,35} \\
\hline $\operatorname{Prob}>\operatorname{ch} 2$ & \multicolumn{2}{|c|}{$(0,2808)$} & \multicolumn{2}{|c|}{$(0,0022)^{* * *}$} \\
\hline \multicolumn{5}{|l|}{ Fisher test } \\
\hline $\mathbf{F}$ & \multicolumn{2}{|c|}{2618,81} & \multirow{2}{*}{\multicolumn{2}{|c|}{$\begin{array}{c}8,86 \\
(0,0000)^{* * *} \\
\end{array}$}} \\
\hline Prob $>$ F & \multicolumn{2}{|c|}{$(0,0000)^{* * *}$} & & \\
\hline Nobservations & \multirow{2}{*}{\multicolumn{2}{|c|}{$\begin{array}{c}516 \\
8365 \%\end{array}$}} & \multicolumn{2}{|c|}{295} \\
\hline$R^{2}$ overall & & & \multicolumn{2}{|c|}{$17,59 \%$} \\
\hline
\end{tabular}

Note. CFO: Operating cash-flows; AD: discretionary accruals; AND: non discretionary accruals; $* * *$ significant at the level of $1 \%$, $* *$ significant at the level of $5 \%$, significant at the level of $10 \%$. 
It is Hausman's specification test which served to decide about the use of model fix effect or aleatory model. This test proves that the fix effect model is better adapted for the date in both contexts for the period before adoption of IAS norms. The synthesis results in the table 5 exposes that the discretionary accrual impact on the prediction of future cash-flow of exploitation is significantly negative for the U. K whereas, it is positive for France. As far as the non-discretionary accruals, the estimations prove the positive significant impact for the British context, but no impact has been found for France. The same remark is indeed for the cash-flow of exploitation. The Fisher's test linked to the global validity of the model announces that the last is globally significant for both countries. In addition, the $R^{2}$ presents the most important value in the British context.

The obtained findings above are found in conformity with that was interpreted by Subramanayam (1996) and Krishnan (2003). Both of them justified that the three components of the accounting results, the treasury flow the discretionary accruals and the non-discretionary accruals, are associated with the future profitability of the firm. Badertsher et al. (2012) demonstrated that the predictive capacity of the discretionary for the future operating cash-flows depends on the reason for which the managers make their discretionary choices. Such a choice could be made either by the opportunistic intentions, informational or contractual. In order to achieve this study, the authors compared the predictive power of the data in relation to those published. These authors demonstrated that the companies classified as making accrual choices for opportunistic reasons, are retired information which represent the predicative power the most interesting for the future cash-flows than the really published data. Moreover, they remarked that in this case, the published data are not significantly associated with the future cash-flows. However, for the firms classified as opting for the choice of non-opportunistic discretionary choices, the results are consistent with the informational hypothesis than the initially published accruals which have a predicative capacity more interesting for the future cash-flow of exploitation than the retired data. Also, discretionary accrual component is significantly associated to the future cash-flow whereas; no accruals component is significantly associated to future cash-flows. This synthesized information at the level of the discretionary accrual component reflects the discretionary accounting choices of managers. Indeed, managerial dispose discretion margin for the verification of charges. This discretion could be used by managers to the private information or for manipulating in an opportunistic way the earnings.

Badertsher et al. (2012) suggest that the informational motivation of discretionary choices could be set up with regard to the limits of accounting principles generally admitted or outside these limits. Being classified as of second-hand choices, the considered choices by the normative and/or by auditors as not allowed by the accounting principles generally admitted and once fourth detected leading to retirements. However, we find the accounting principles generally admitted, offering to the takers some degree of flexibility, interpretation and of judgment essentially when facing a problem of specific accounting technical choices, to the divulgation procedures or of estimation. These principles and the degree of flexibility put at the disposition of decisiontakers, vary though the accounting normalization of the country. The study of the impact of the accounting normalization nature on the capacity of discretionary accruals to foresee the future cash-flow of exploitation is analyzed at the level of the following section.

\subsubsection{The Discretionary Accrual Predictive Quality Analysis after the IAS/IFRS Norms Standards Adoption}

The findings linked to the estimation of the discretionary and non-discretionary component power in the two contexts after the IAS norms adoption are summarized in Table 6. The Hausman's test shows that the fix effect model, which is the most adapted to the data of both countries. As for the British context, the estimation shows that both discretionary and non-discretionary components of accruals, positively and significantly affect the future cash-flow of exploitation at the level of $1 \%$; The model is globally significant at the level of $1 \%$ and the $\mathrm{R}^{2}$ is of a highly value $(93.6 \%)$. In the French context, the model is globally significant and all explicative variables prove a significant positive predicative capacity at the level of $1 \%$.

To synthesize, we can interpret that the alignment between the predicative power of the components of accounting results after the adoption of IFRS norms has been some dimensions and not for others. Such alignment has been left for the discretionary and non-discretionary accrual power whereas the divergences are identified at the level cash-flow of exploitation. Therefore, we can say that although we are located in two countries proceeding to the application of the same accounting principles for the preparation of the financial information, the output of the financial divulgation do not seem to produce the same predicative power for the future cash-flows. These results come to confirm the explanation presented in the internal accounting lit, which indicate that the accounting principle do not allow the only to determine the quality of financial divulgation. (Ball, Robin, \& Wu, 2003; Leuz, Nanda, \& Wysocki, 2003; Leuz \& Wysocki, 2008) and that there are other forces which influence such an output as the accounting legislation and its application/put into practice. 
Table 6. Synthesis of statistics related to regression of future operating cash flows on past operating cash-flows and the component discretionary and non discretionary accruals

\begin{tabular}{|c|c|c|c|c|}
\hline \multirow{3}{*}{ Variable } & \multicolumn{4}{|c|}{$\boldsymbol{C} \boldsymbol{F}_{i, t}=\beta_{0}+\beta_{1} \boldsymbol{C} \boldsymbol{F}_{i, t-1}+\beta_{2} A D_{i, t-1}+\beta_{3} A N D_{i, t-1}+\varepsilon_{i, t}($ Model 1) } \\
\hline & \multicolumn{2}{|c|}{ Grande Bretagne } & \multicolumn{2}{|c|}{ France } \\
\hline & Coef & P-value & Coef & P-value \\
\hline $\mathrm{CFO}_{t-1}$ & 0,125 & $(0,317)$ & 1,201 & $(0,000)^{* * *}$ \\
\hline$A D_{t-1}$ & 242,8021 & $(0,000)^{* * *}$ & 14,443 & $(0,002)^{* * *}$ \\
\hline
\end{tabular}

\begin{tabular}{|c|c|c|}
\hline \multicolumn{3}{|c|}{ Hausman test } \\
\hline Chi2 & 51,64 & 94,14 \\
\hline Prob $>$ ch 2 & $(0,0000)^{* * *}$ & $(0,0000)^{* * *}$ \\
\hline \multicolumn{3}{|c|}{ Breusch-Pagen test } \\
\hline Chi2 & 3,81 & 0,13 \\
\hline Prob $>$ ch 2 & $(0,0982)^{*}$ & $(0,7204)$ \\
\hline \multicolumn{3}{|l|}{ Fisher test } \\
\hline $\mathbf{F}$ & 124631,72 & 659,49 \\
\hline Prob $>$ F & $(0,0000) * * *$ & $(0,000)^{* * *}$ \\
\hline Nobservations & 380 & 238 \\
\hline$R^{2}$ overall & $93,67 \%$ & $14,68 \%$ \\
\hline RMSE & 930,996 & 0,96 \\
\hline
\end{tabular}

Note. CFO: Operating cash-flows; AD: discretionary accruals; AND: non discretionary accruals; $* * *$ significant at the level of $1 \%$, $* *$ significant at the level of $5 \%$, * significant at the level of $10 \%$.

Holthausen (2009) suggest that many factors allow modelizing the financial disclosure quality and that the accounting principle represent only one of these factors. He adds that the impact of these principles is power felt compared to that of other determinants and as the managers incitation's, the auditor quality, the legislation and its application, the structure of the propriety. In this sense, Mahoney (2009) conclude that the legislation of the financial market and its put into practice, may lead to important divergence at the result level of the financial disclosure.

Coffee (2007) has already interpreted that it is not enough to understand the law, on the contrary the understanding of the manner with which they are put into vigor would be of determining results for the discreet of economic and financial divulge.

All these expositions have important implications for the interpretation of the effect of the IFRS standards adoption on the financial divulge all over the world. In fact, the adoption of these norms worldwide was produced quickly under the hypothesis that it will be an advantage in producing a uniform level of principles for the final divulge and consequently make the comparison between the enterprises across the countries easier and more transparent. However, we remark from the results of our study that this objective was not completely achieved and that the main differences are at the level of the accounting information quality, in terms of its predicative capacity in France and in the UK after the adoption of IFRS standards.

These results may be explained from what have been presented in the international literature concerning the adoption of IFRS and its impact. Indeed, in both countries of our study, in spite of speaking of the application of the same accounting principle level, the differences at the environment level of the financial divulge is still there. This was explication of a common level of accounting principle across the countries does not seem to at a similar quality at the financial disclosure level only if other powers which govern the financial state quality become similar across the countries. Ball (2006) for him he considered that it would be naif to believe in uniform accounting norms producing inevitably uniform financial states in the measure that the accounting choices are dictated by political and economic considerations essentially local ones. He is rather in favor of maintaining some competitiveness between the norms.

In our study, both European countries selected to test the impact of the IFRS adoption on the predictive power of the accounting information belong to two different classes. The first to the class of Anglo- Saxon countries (UK) and the second to the Euro- continental (France). The IFRS norms are base on the principles of the common law, according to which the legal rules come from the legal prudence, and consequently it is the same orientation of the British context. 
The same for France, we have to remind that it is a country of strong tradition and the adoption of the IFRS norms constitute an important move at the level of objectives of the financial disclosure. Ayoub and Hooper (2008) have synthesized the differences between the IFRS norms and the French norms in three big points. The first is linked to the notion of fair value which is unknown to the French accountants who base their work on the historic cost. The second is that France has always favored Inland Revenue on the financial communication; whereas, the new referential, favors the real economic value of the enterprise, and the production of a faithful image in order to satisfy the informative needs of investors. The third point is linked to the structure even of the IFRS that do not have according to Ayoub and Hooper (2008) equivalent in France. Indeed, these norms let a wide place for interpretation whereas, the French accountant are used to follow a very precise instructions of the General Accounting Plan.

Raffournier (2007) suggested that the decision of the European Union to make The IFRS compulsory for the enterprises quoted to solicit many negative reactions in the academic and economic environment. He attributed this hostility to the deep change of accounting philosophy which imply the adoption of the IFRS and to the difficulties for some actors of the process of accounting normalization to accept to be dispossessed of their prerogative in the material. He explain that in general, the introduction of the IFRS norms that represent the Anglo-Saxon conception of accounting, in most of Euro-continental countries mark a true cultural revolution by the accounting philosophy move that it represents. Such an interpretation may explain the result of our study, for which we did not identify the net variation at the level of the predicative power of the accounting information before and after the adoption of the IFRS norms in the British context. In the contrary, in the French context, we notice an important upside down at the level of this power before and after. It is essentially at the level of accruals and their components that we remarked this variation.

Such a suggestion has already been practically approved by Ayoub and Hooper (2008), who with their interviews semi directive with chartered accounts, auditors, and academics in France, they looked for identifying the cultural reasons that pushed French people to have negative attitudes vis-à-vis the IFRS. They showed that variables as the language, the religion, the social organization or more politics could bring elements of supplementary response to resist international norms.

Colasse (2006) has already declared that "more than the technical problems that their put into practice was able to do, the international standards, and it is their main stake, are bringers of a governing way in stage with a capitalism of financial market". Chiapello (2005) has gone further by writing that "the international standards tend to put forward the enterprise as being before all merchandise whose financial markets do business, and not as an institution producing and selling goods".

Raffournier (2007) added to all these explanations that the IFRS norms lay down so major difficulties in practice to be used in the French context. Indeed, in France and according to Garnier's (1947) formula, accounting is "algebra of the right"; in other words, accounting has to reflect the juridical relations between the enterprise and the thirds. This is not the case for the IFRS where the accounting information must privilege the economic analyses. Therefore, the IFRS application in France presents a true cultural break, what's more is that it requires new competences on the part of practitioners of accounting. In reality, in France the economic teaching, in particular the financial analysis had not been absent in the programs but they did not have a central place. The application of the IFRS requires on the other hand, that accountants have a deep financial education, which is not the case for the Anglo-Saxon accounts whose training has ever made a larger place for the financial and economic analysis.

To study the impact the international norms adoption on the predicative quality of the accounting information in the two European countries, more precisely, on the quality of discretionary accruals, consists the object of our next part.

\subsubsection{Impact of the IAS/IFRS International Norms on the Predicative Quality of the Discretionary Accruals}

The synthesized findings in Table 7 shows the three components of the accounting result that are associated significantly at the level of $1 \%$ with the future cash-flows. This link is positive for the cash-flows and the anterior non discretionary accruals whereas it is negative for the past discretionary accruals. The coefficient $\beta_{5}$ measures the association with the discretionary accruals and the future cash-flows of the companies using international norms compared to those using the British standards. This coefficient is positive, which imply that the association between the discretionary accruals and the future cash-flows is more important for the enterprise using the international norms than the other ones. These results confirm our hypothesis that the international norms allow improving the quality of the accounting information, essentially those of the discretionary accruals in the British context. 
Table 7. Synthesis of statistics related to regression of future operating cash flows on past operating cash-flows, discretionary accruals, non discretionary accruals, and discretionary accruals related to the nature of accounting standards: British standards against international standards

\begin{tabular}{|c|c|c|c|}
\hline \multicolumn{4}{|c|}{$C F_{i, t+1}=\beta_{0}+\beta_{1} C F O_{i, t}+\beta_{2} A D_{i, t}+\beta_{3} A N D_{i, t}+\beta_{4} I F R S_{i, t}+\beta_{5} A D_{i, t} * I F R S_{i, t}+\varepsilon_{i, t}$ (Model 3) } \\
\hline Variable & Coefficient & t-student & P-value \\
\hline Constant & $-1,051$ & 1,75 & $(0,017) * *$ \\
\hline $\mathrm{CFO}_{i, t}$ & 0,564 & 23,80 & $(0,000)^{* * *}$ \\
\hline$A D_{i, t}$ & 0,562 & 22,16 & $(0,002)^{* * *}$ \\
\hline$A N D_{i, t}$ & 0,048 & 22,46 & $(0,000)^{* * *}$ \\
\hline $\operatorname{IFRS}_{i, t}$ & 0,840 & 1,26 & $(0,208)$ \\
\hline$A D * I F R S_{i, t}$ & 0,498 & 17,29 & $(0,000)^{* * *}$ \\
\hline$N$ & \multicolumn{3}{|c|}{893} \\
\hline$F$ & \multicolumn{3}{|c|}{$592,95(0,0000) * * *$} \\
\hline$R^{2}$ & \multicolumn{3}{|c|}{$76,97 \%$} \\
\hline $\operatorname{Adj}-R^{2}$ & \multicolumn{3}{|c|}{$76,84 \%$} \\
\hline RMSE & \multicolumn{3}{|c|}{9,7221} \\
\hline
\end{tabular}

Note. CFO: Operating cash-flows; AD: discretionary accruals; AND: non discretionary accruals; *** significant at the level of $1 \%$, ** significant at the level of $5 \%, *$ significant at the level of $10 \%$.

Table 8. Synthesis of statistics related to regression of future operating cash flows on past operating cash-flows, discretionary accruals, non discretionary accruals, and discretionary accruals related to the nature of accounting standards: French standards against international standards

\begin{tabular}{|c|c|c|c|}
\hline \multicolumn{4}{|c|}{$C F_{i, t+1}=\beta_{0}+\beta_{1} C F O_{i, t}+\beta_{2} A D_{i, t}+\beta_{3} A N D_{i, t}+\beta_{4} I F R S_{i, t}+\beta_{5} A D_{i, t} * I F R S_{i, t}+\varepsilon_{i, t}$ (Model 3) } \\
\hline Variable & Coefficient & t-student & P-value \\
\hline Constant & 0,883 & 1,83 & $(0,017)^{* *}$ \\
\hline $\mathrm{CFO}_{i, t}$ & 1,174 & 25,87 & $(0,000)^{* * *}$ \\
\hline$A D_{i, t}$ & 0,636 & 3,66 & $(0,002)^{* * *}$ \\
\hline$A N D_{i, t}$ & 0,418 & 5,84 & $(0,000)^{* * *}$ \\
\hline $\operatorname{IFRS}_{i, t}$ & $-0,899$ & $-1,35$ & $(0,177)$ \\
\hline$A D_{i, t} * I F R S_{i, t}$ & $-0,572$ & $-0,10$ & $(0,918)$ \\
\hline$N$ & & 535 & \\
\hline$F$ & & $354,78(0,0000) * * *$ & \\
\hline$R^{2}$ & & $77,703 \%$ & \\
\hline $\operatorname{Adj}-R^{2}$ & & $76,81 \%$ & \\
\hline RMSE & & 6,9794 & \\
\hline
\end{tabular}

Note. CFO: Operating cash-flows; AD: discretionary accruals; AND: non discretionary accruals; *** significant at the level of $1 \%$, ** significant at the level of $5 \%, *$ significant at the level of $10 \%$.

Consulting Table 8 proves that the French context and the three components of the accounting results are related to the cash-flows of future exploitation along the study period from 1999 until 2008. All the coefficients are $\beta_{1}$, $\beta_{2}$ and $\beta_{3}$ are significantly positive at the level of $1 \%$. The coefficient B5 measure the supplementary association between the discretionary accruals and the cash-flows of future exploitations for the firms using the international norms compared to those using the French ones. The sum of $\beta_{2}$ and $\beta_{4}$ represents the link between the discretionary accruals and the future for the enterprise using the international standards during the period (2004-2008). As far as the impact of the international norms on the predicative quality of the discretionary accruals, the results show a B5 non significant. This does not imply that the French standards and the international ones are identical. And supply accounting information of similar quality. But rather, because of the nature of the French accounting environment, the application of the accounting standards essentially oriented to the satisfaction of investors needs', characterized by an enormous flexibility may not achieve the wished objectives.

The second hypothesis of our analytical study of the adoption of the same level of accounting principles, the IFRS by the two European countries in the alignment of the predictive power of the component of the accounting results. The results are able to reveal that the level of alignment wished essentially in the dimensions that grasp the accounting principles, that is to say the discretionary accruals, is not achieved. These results confirm what 
has been developed in the international accounting literature, that the accounting principle is not the only determinant of the quality of financial divulges and that other powers influence such output as the accounting legislation and their application.

Also, this difference at the level of the detected result in both countries, members of the European Union after the adoption of the IFRS norms, could be explained by the fact that for France, the accounting legislation belongs to the state ; whereas for the U.K, it belongs to professionals. Thus, we notice that for the U.K, the adoption of the IFRS does not constitute a real upside down because it translates only the replacing of professionals by others who share the same philosophy. In the contrary, for France the introduction of these standards represents a modification of accounting philosophy of this country, and leads to many difficulties of application. It is in this sense that Christensen et al. (2009) explained that the U.K which is a country characterized by a very developed and ruled financial market; and the fact that the disclosure with reference to the UK GAAP is comparable to those prepared according to IFRS. It does not seem that the accounting results prepared by the transition of the UK GAAP towards the IFRS offer unique information about cash -flows. Nevertheless, because the accounting information is served to satisfy investors' needs, the technical variation at the level of earnings calculation may influence the wealth distribution between shareholders and creditors. Consequently, the institutional factors as the high level of rules of the financial market may affect substantially the differences of the evaluation by the financial market of the divulged information.

These interpretations are found reinforced by our findings during the estimation of the impact of the international norms on the predicative quality of discretionary accruals. Indeed, the results prove that the international norms react positively on the predicative capacity of discretionary accruals in the British context. However, no impact has been detected in the French context. This allows us to confirm previous developments that for the international norms to achieve the wished objectives, they must be applied in adaptation with the environment factors of the country.

4.2.4 The Legal System and Its Impact on the Predicative Quality of the Discretionary Accruals before Adoption of IAS/ IFRS Norms

Table 9 represents the estimated results linked to the impact of legal system on the predicative quality of the discretionary accruals during the period before adoption of the IAS/IFRS norms. They allow demonstrating that the different components of the results are related significantly to the level of $1 \%$ with cash flow of future exploitation. This result is coherent with those of Subramanyam (1996) and Krishnan (2003). This link is positive for the cash flow of exploitation and the non discretionary accruals passed whereas it is negative for the discretionary accruals. As far as the norms used, the coefficient $\beta_{4}$ is negative at the level of $1 \%$ which imply that our model is sensitive to the nature of the legal regime of the country. In other words, the application of the British accounting standards affects negatively the prediction of cash flow of future exploitation. The coefficient $\beta_{5}$ measures the link between the discretionary accruals and the cash flow of exploitation of enterprises using the British norms compared to those using the French norms. This coefficient $(20,428 ; P$-value $=0,000)$ is associated significantly and positively to the legal system which affects the predicative quality of discretionary accruals. The positive sign implies that the fullness of the link of the association between the cash flow of future exploitation and the discretionary accruals is higher for the enterprises using the French norms compared to those using the British norms.

This result leads us to say that compared to the French, the British norms are more able to limit the opportunistic practices of managers. Indeed, although, the British norms are characterized by an important degree of flexibility, one norm suggests many options and the characteristics of its financial environment limit the opportunistic behavior of the decision-takers.

For the period after adoption, the estimations show that the British legal regime affects significantly and positively the prediction of future operating cash-flows which proves that the two countries the apply the same level of accounting principles, the nature of the political system remains a determining element of the quality of the accounting information. The coefficient $\beta_{5}(10,121 ; P$-Value $=0,000)$ show that the fullness of the link between the cash flow of future exploitation and the discretionary accruals is more important for the enterprise using the UK standards compared to those using the French ones. 
Table 9. Synthesis of statistics related to regression of future operating cash flows on past operating cash-flows, discretionary accruals, non discretionary accruals, and discretionary accruals related to the nature of accounting standards: UK standards against French standards before IFRS

\begin{tabular}{|c|c|c|c|}
\hline \multicolumn{4}{|c|}{$\begin{aligned} C F O_{\mathrm{i}, \mathrm{t}+1}= & \beta_{0}+\beta_{1} C F O_{\mathrm{i}, \mathrm{t}}+\beta_{2} A D_{\mathrm{i}, \mathrm{t}}+\beta_{3} A N D_{\mathrm{i}, \mathrm{t}}+\beta_{4} U K_{\mathrm{i}, \mathrm{t}}+\beta_{5} A D_{\mathrm{i}, \mathrm{t}} * U K_{\mathrm{i}, \mathrm{t}}+\varepsilon_{i, t}(\text { Model } 3) \\
& \text { (global sample: } \text { French and } \mathrm{U} \text { combined effect of legal system) }\end{aligned}$} \\
\hline \multicolumn{4}{|l|}{ Panel A } \\
\hline \multirow[b]{2}{*}{ Variable } & \multicolumn{2}{|c|}{ Avant adoption des normes IAS/IFRS } & \multirow[b]{2}{*}{ P-value } \\
\hline & Coefficient & t-student & \\
\hline Constante & 1,602447 & 2,12 & $(0,035)^{* *}$ \\
\hline $\mathrm{CFO}_{i, t}$ & 0,6917 & 27,10 & $(0,000)^{* * *}$ \\
\hline$A D_{i, t}$ & 21,327719 & 3,36 & $(0,000)^{* * *}$ \\
\hline$A N D_{i, t}$ & 0,4064 & 6,47 & $(0,000)^{* * *}$ \\
\hline$U K_{i, t}$ & $-3,563$ & $-4,98$ & $(0,000)^{* * *}$ \\
\hline$A D_{i, t} * U K_{i, t}$ & 20,42856 & 3,22 & $(0,000) * * *$ \\
\hline$N$ & \multicolumn{3}{|c|}{802} \\
\hline \multirow[t]{2}{*}{ Wald test } & \multicolumn{3}{|c|}{1309,36} \\
\hline & \multicolumn{3}{|c|}{ Prob $>$ chi $2=(0,0000) * * *$} \\
\hline$R^{2}$ Overall & \multicolumn{3}{|c|}{$62,19 \%$} \\
\hline \multicolumn{4}{|l|}{ Panel B } \\
\hline \multicolumn{4}{|c|}{ Après adoption des normes IAS/IFRS } \\
\hline Variable & Coefficient & t-student & $P$-value \\
\hline Constante & 0,0784099 & 0,1 & 0,923 \\
\hline$C F_{i, t}$ & 0,1954571 & 5,46 & $(0,000)^{* * *}$ \\
\hline$A D_{i, t}$ & 0,9455241 & 81,35 & $(0,000)^{* * *}$ \\
\hline$A N D_{i, t}$ & 0,3584546 & 22,01 & $(0,000) * * *$ \\
\hline$U K_{i, t}$ & 4,740196 & 4,57 & $(0,000)^{* * *}$ \\
\hline$A D_{i, t} * U K_{i, t}$ & 10,12095 & 18,21 & $(0,000)^{* * *}$ \\
\hline$N$ & \multicolumn{3}{|c|}{619} \\
\hline \multirow[t]{2}{*}{ Wald test } & \multicolumn{3}{|c|}{101694,77} \\
\hline & \multicolumn{3}{|c|}{ Prob $>$ chi $2=(0,000) * * *$} \\
\hline$R^{2}$ overall & \multicolumn{3}{|c|}{$99,44 \%$} \\
\hline RMSE & \multicolumn{3}{|c|}{12,536} \\
\hline
\end{tabular}

Note. CFO: Operating cash-flows; AD: discretionary accruals; AND: non discretionary accruals; *** significant at the level of $1 \%$, ** significant at the level of $5 \%$, * significant at the level of $10 \%$.

\section{Conclusion}

The adoption of the IAS/IFRS by many countries and their impact on the quality of financial disclosure has solicited numerous reactions in the academic and professional field of accounting. (Flower, 1997; Zeff, 1998; Ball, 2001; Hope, 2003; Hope et al., 2006; Meulen et al., 2007; Ding et al., 2007; Soderstrom \& Sun, 2007; Barth et al., 2008; Clacher, Ricqebourg, \& Hodgson, 2013).

The purpose of this article is to study the impact of the adoption of the IAS/ IFRS norms on the pertinence of discretionary accruals in terms of their capacity to forecast the future operating cash-flows of future exploitation in two European countries of two different classes. The first, the UK being included under the Anglo-Saxon class which is characterized by a very developed financial market and financial information designed essentially to satisfy the investors' needs. The second, France which is belonging to a Euro-continental group characterized by a narrow link between Inland Revenue, accounting and accounting information supplied to satisfy the government needs.

Based on a sample composed of quoted companies in SBF 120 for the French context and FTSE 500 for the British ones. The findings of our study show that the application of the IAS/IFRS allows improving the predictive quality of discretionary accruals in the British context. Indeed, the negative impact during the before -adoption-period, we have detected a significant and positive impact along the after- adoption-period. In the French context, the predictive quality of discretionary accruals for future cash-flows is more important for the firms using the international norms than in those applying the British ones. In the French context, no impact has been proved for the IAS/IFRS on the predictive quality of the discretionary accruals. This does not imply that the 
French and the international norms are similar and supply a similar quality accounting information. But rather, because of the nature of the French accounting norms which are essentially designed to the satisfaction of the investors needs and characterized by high flexibility may not lead to achieve the desired objectives. These results confirm what was developed in the international accounting literature, that the accounting principles do not represent the only determinant of the quality of financial divulge and that other forces influence such output as the accounting laws, and the put into application. Similarly, this difference detected at the level of results in both states members of the European Union after the adoption of the IFRS norms, could be explained by the fact that for France, the making of accounting laws belongs to the government whereas in the UK, the adoption of the IFRS norms does not constitute a fundamental upside down because it is simply translated by replacing the professionals by others who share the same philosophy. In the contrary, for France, the introduction of the IFRS represents a modification of the accounting philosophy of the country and represents many difficulties of applications.

The findings of our study prove that the legal regime of countries affects the predictive quality of discretionary accruals. According to the domestic principles (period before adoption), the discretionary accruals are better evaluated in the U.K. than in France. The same results have been deduced for the period after adoption.

In our point of view, this study, contributes to spread the anterior literature linked to the quality of the information carried by the discretionary accruals. Our bringing could be summarized in three points of views. First, we have estimated the pertinence of the discretionary accruals in terms of their capacity to forecast future operating cash-flows with a comparative study between two countries presenting different characteristics in legislation of financial market. Second, we have studied the effect of adoption of the IAS/IFRS norms. Third, we have tested the impact of the legal regime of a country on the predicative quality of discretionary accruals for both periods: before and after adoption. To our knowledge, this study is the first to tackle the way with which the IFRS affect the pertinence of the discretionary accruals in two contexts characterized by different legal systems.

In spite of our study bringing, it seems that our results should be interpret with caution. Indeed, to study the predictive power of the discretionary accruals on a sample of heterogeneous enterprises may be a source of bias. Some recent methodological refining and a better consideration of contextual variables, would be pertinent to test the predicative power of the accounting information.

Even though in our study we tried to supply a rich theoretical and empirical work, many ways of future researches remain contemplative to predict the future cash flow. Moreover, spreading the analysis to other countries will allow to better estimate the country effect and the differences between domestic principles and the IFRS on the pertinence of the discretionary accruals.

\section{References}

Aboody, D., Barth, M., \& Kasznik, R. (1999). Revaluation of fixed asset and future firm performance. Journal of Accounting and Economics, 26, 149-178. http://dx.doi.org/10.1016/S0165-4101(98)00040-8

Altamuro, J., Beatty, A., \& Weber, J. (2005). The effects of accelerated revenue recognition on earnings management and earnings Informativeness: Evidence from SEC staff accounting bulletin No. 101. The Accounting Review, 80(2), 373-401. http://dx.doi.org/10.2308/accr.2005.80.2.373

Arya, A., Fellingham, J., Glover, J., \& Schroeder, D. (2002). Depreciation in a model of probabilistic investment. The European Accounting Review, 11(4), 681-698. http://dx.doi.org/10.1080/09638180220125607

Ashbaugh, H., \& Pincus, M. (2001). Domestic Accounting Standards, International Accounting Standards, and the predictability of earnings. Journal of Accounting Research, 39(3), 417-434. http://dx.doi.org/10.1111/1475-679X.00020

Aussenegg, W., Inwinkl, P., \& Schneider, G. (2009). Earning management and accounting standards in Europe. MFA Annual Meeting.

Ayoub, S., \& Hooper, K. (2008). Les freins culturels à l'adoption des IFRS: Une analyse du cas français. Revue Sciences de Gestion, 68, 117-136.

Badertscher, B. (2011). Overvaluation and the choice of alternative earnings management mechanisms. Accounting Review, 86(5), 1491-1518. http://dx.doi.org/10.2308/accr-10092

Badertscher, B. A., Collins, D. W., \& Lys, T. Z. (2012). Discretionary accounting choices and the predictive ability of accruals with respect to future cash flows. Journal of Accounting and Economics, 53(1/2), 330-352. http://dx.doi.org/10.1016/j.jacceco.2011.11.003

Ball, R. (2001). Infrastructure requirements for an economically efficient system of public financial reporting 
and disclosure. Brookings Wharton Papers on Financial Services, 127-182. http://dx.doi.org/10.1353/pfs.2001.0002

Ball, R. (2006). International financial reporting, (IFRS), pros and cons for investors. Accounting and Business Research, 36, 5-27. http://dx.doi.org/10.1080/00014788.2006.9730040

Ball, R., \& Shivakumar, L. (2008). Earnings quality at initial public offerings. Journal of Accounting Economics, 45(2), 324-349. http://dx.doi.org/10.1016/j.jacceco.2007.12.001

Ball, R., Kothari, S., \& Robin, A. (2000). The Effect of International Institutional Factors on Properties of Accounting Earnings. Journal of Accounting \& Economics, 29, 1-51. http://dx.doi.org/10.1016/S0165-4101(00)00012-4

Ball, R., Robin, A., \& Wu, S. J. (2003). Incentives versus standards: Properties of accounting income in four East Asian countries. Journal of Accounting and Economics, 36(1-3), 235-270. http://dx.doi.org/10.1016/j.jacceco.2003.10.003

Bartov, E., Goldberg, S., \&Kim, M. (2005). Comparative value relevance among German, US, and International Accounting Standards: A German stock market perspective. Journal of Accounting, Auditing \& Finance, 20(2), 95-119.

Basu, S., Hwang, L., \& Jan, C. (1998). International Variation In Accounting Measurement Rules and Analysts' Earnings Forecast Errors. Journal of Business Finance \& Accounting, 25, 1207-1247. http://dx.doi.org/10.1111/1468-5957.00234

Beneish, M. D. (2001). Earnings management: A perspective. Managerial Finance, 27(12), 3-17. http://dx.doi.org/10.1108/03074350110767411

Boumediene, E., Boumediene, S. L., \& Nafati, O. (2014). Impact of Adoption IAS-IFRS on the Handling of Accounting Data: The Case of France. The Journal of Applied Business Research, 30(4), 1239-1252.

Bruggermann, U., Daske, H., Homberg, C., \& Pope, P. F. (2009). How Do Individual Investors React to Global IFRS Adoption.

Burns, J. (2000). The dynamics of accounting change: Interplay between new practices, routines, institutions, power and politics. Accounting, Auditing \& Accountability Journal, 13(5), 566-596. http://dx.doi.org/10.1108/09513570010353710

Capron, M., \& Chiapello, E. (2005). Les normes comptables internationales, instruments du capitalisme financier. 49-87.

Chan, K., Chan, L. K. C., Jegadeesh, N., \& Lakonishok, J. (2006). Earnings quality and stock returns. Journal of Buiness, 79(3), 1041-1082. http://dx.doi.org/10.1086/500669

Chiapello, E. (2005). Les normes comptables comme institution du capitalisme: Une analyse du passage aux normes IFRS en Europe à partir de 2005. Sociologie du Travail, 47(3), 362-382. http://dx.doi.org/10.1016/j.soctra.2005.06.002

Choi, F. D. S. (1991). Accounting and control for multinational activities: Perspective on the 1990's. Management International Review, 31(1), 97-110.

Christensen, H. B., Lee, E., \& Walker M. (2008). Incentives or standards: What determines accounting quality changes around IFRS adoption? AAA 2008 Financial Accounting and Reporting Section (FARS) Paper. Retrieved from http://ssrn.com/abstract=1013054

Christensen, H. B., Lee, E., \& Walker, M. (2008). Do IFRS Reconciliation Convey Information? The effect of Debt Contracting. Journal of Accounting Research, 47(5), 1167-1199. http://dx.doi.org/10.1111/j.1475-679X.2009.00345.x

Clacher, I., Ricqebourg, A. D. D., \& Hodgson, A. (2013). The value relevance of direct cash -flows under IFRS. Working paper, Mars 2013.

Coffee, J. C. (2007). Law and the market: The impact of enforcement. University of Pennsylvania Law Review, 156, 229-258. http://dx.doi.org/10.2139/ssrn.967482

Colasse, B. (2006). IFRS: Un défi \& une opportunité pour l'enseignement de la comptabilité. Revue Française de Comptabilité, 385, 37-40.

Cormier, D., Ledoux, M., \& Villeneuve, G. (2011). Value Relevane of Discretionary Accruals in France and the UK., The Incidence of IFRS. Working paper, 2011-3, ESG-UQAM. 
Daske, H., Hail, L., Leuz, C., \& Verdi, R. (2008). Mandatory IFRS reporting around the world: Early evidence on the economic consequences. Journal of Accounting Research, 46(5), 1085-1142. http://dx.doi.org/10.1111/j.1475-679X.2008.00306.x

Dechow, P. M., \& Dichev, I. D. (2001). The quality of accruals and earnings: The role of accruals estimation errors. The Accounting Review, 77, 35-59. http://dx.doi.org/10.2308/accr.2002.77.s-1.35

Dechow, P. M., \& Skinner, D. J. (2000). Earnings management: Reconciling the views of accounting academics, practitioners, and regulators. Accounting Horizons, 14, 235-251. http://dx.doi.org/10.2308/acch.2000.14.2.235

Dechow, P. M., Sloan, R. G., \& Sweeney, A. P. (1995). Detecting Earnings Management. The Accounting Review, 70(2), 193-225.

DeFond, M. L., \& Jiambalvo, J. (1994). Debt covenant violation and manipulation of accruals. Journal of Accounting and Economics, 17(3), 145-176. http://dx.doi.org/10.1016/0165-4101(94)90008-6

Degeorge, F., Patel, J., \& Zeckhauser, R. (1999). Earnings management to exceed thresholds. Journal of Business, 72(1), 1-33. http://dx.doi.org/10.1086/209601

Demski, J. S. (1998). Performance measure manipulation. Contemporary Accounting Research, 15(3), 261-285. http://dx.doi.org/10.1111/j.1911-3846.1998.tb00560.x

Ding, Y., Hope, O. K., Jeanjean, T., \& Stolowy, H. (2007). Differences between domestic accounting standards and IAS: Measurement, determinants and implications. Journal of Accounting and Public Policy, 26(1), 1-38. http://dx.doi.org/10.1016/j.jaccpubpol.2006.11.001

Dumontier, P., \& Raffournier, B. (1998). Why firms comply voluntarily with IAS: An empirical analysis with Swiss data. Journal of International Financial Management and Accounting, 9(3), 216-245. http://dx.doi.org/10.1111/1467-646X.00038

Eccher, E., \& Healy, P. (2003). The Role of International Accounting Standards in Transitional Economies: A Study of the People's Republic of China, Working paper, Massachusetts Institute of Technology.

Elliott, J. A., \& Philbrick, D. R. (1990). Accounting changes and earnings predictability. The Accounting Review, 65(1), 157-174.

Flower, J. (1997). The future shape of harmonization: The EU versus the IASC versus the SEC. The European Accounting Review, 6(2), 281-303. http://dx.doi.org/10.1080/713764723

Foster, G. (1986). Financial Statement Analysis. Englewood Cliffs, Prentice-Hall.

Ghosh, A., Marra, A., \& Moon, D. (2010). Corporate boards, audit committees, and earnings management: Pre-and post-SOX evidence. Journal of Business, Finance and Accounting, 37(9/10), 1145-1176. http://dx.doi.org/10.1111/j.1468-5957.2010.02218.x

Ghosh, D., \& Olsen, L. (2009). Environmental Uncertainty and Managers' Use of Discretionary Accruals. Accounting, Organizations and Society, 34(2), 188-205. http://dx.doi.org/10.1016/j.aos.2008.07.001

Guenther, D., \& Young, D. (2000). The association between financial accounting measures and real economic activity: A multinational study. Journal of Accounting and Economics, 29(1), 53-72. http://dx.doi.org/10.1016/S0165-4101(00)00013-6

Guidry, F., Leone, A. J., \& Rock, S. (1999). Earnings-based bonus plans and earnings management by business-unit managers. Journal of Accounting and Economics, 26(1), 113-142. http://dx.doi.org/10.1016/S0165-4101(98)00037-8

Gul, F., Chen, C., \& Tsui, J. (2003). Discretionary Accounting Accruals, Managers' Incentives, and Audit Fees. Contemporary Accounting Research, 20(3), 441-464. http://dx.doi.org/10.1506/686E-NF2J-73X6-G540

Haw, I., Hu, B., Hwang, L., \& Wu, W. (2004). Ultimate ownership, income management, and legal and extra-legal institutions. Journal of Accounting Research, 42(2), 423-462. http://dx.doi.org/10.1111/j.1475-679X.2004.00144.x

Healy, P. M. (1985). The effect of bonus schemes on accounting decisions. Journal of Accounting and Economics, 7(1/2/3), 85-107. http://dx.doi.org/10.1016/0165-4101(85)90029-1

Healy, P., Kang, S., \& Palepu, K. (1987). The effect of accounting procedure changes on CEOs' salary and bonus compensation. Journal of Accounting and Economics, 9(1), 7-34. http://dx.doi.org/10.1016/0165-4101(87)90015-2 
Holthausen, R. (2009). Accounting Standards, Financial Reporting Outcomes, and Enforcement. Journal of Accounting Research, 47(2), 447-458. http://dx.doi.org/10.1111/j.1475-679X.2009.00330.x

Holthausen, R. W., Larcker, D. F., \& Sloan, R. G. (1995). Annual bonus schemes and the manipulation of earnings. Journal of Accounting and Economics, $19(1), \quad 29-74$. http://dx.doi.org/10.1016/0165-4101(94)00376-G

Holthausen, R., \& Leftwich, R. (1983). The economic consequences of accounting choice: Implications of costly contracting and monitoring. Journal of Accounting and Economics, 5, 77-117. http://dx.doi.org/10.1016/0165-4101(83)90007-1

Hope, O. K. (2003). Firm-level disclosures and the relative roles of culture and legal origin. Journal of International Financial Management and Accounting, 14, 218-248. http://dx.doi.org/10.1111/1467-646X.00097

Hope, O. K. (2004). Variations in the financial reporting environment and earnings forecasting. Journal of International Financial Management and Accounting, 15(1), 21-43. http://dx.doi.org/10.1111/j.1467-646X.2004.00100.x

Hope, O. K., Jin, J., \& Kang, T. (2005). The association between macroeconomic uncertainty and analysts' forecasts accuracy. Journal of International Accounting Research, 4(1), 23-38. http://dx.doi.org/10.2308/jiar.2005.4.1.23

Hope, O. K., Jin, J., \& Kang, T. (2006). Empirical evidence on jurisdictions that adopt IFRS. Journal of International Accounting Research, 5(2), 1-20. http://dx.doi.org/10.2308/jiar.2006.5.2.1

Horton, J., \& Serafeim, G. (2007). Market Reaction and Valuation of IFRS Reconciliation Adjustments: First Evidence from the UK. Working paper, London School of Economics and Political Science and Harvard University.

Hribar, P., \& Jenkins, N. (2004). The effect of accounting restatements on earnings revisions and the estimated cost of capital. Review of Accounting Studies, 9, 337-356. http://dx.doi.org/10.1023/B:RAST.0000028194.11371.42

Hung, M., \& Subramanyam, K. R. (2007). Financial statement effects of the adoption of international accounting standards: The case of Germany. Review of Accounting Studies, 12(4), 623-657. http://dx.doi.org/10.1007/s11142-007-9049-9

Itaridis, G. (2010). IFRS Adoption and Financial Statements Effects, The UK Case. International Journal of Finance and Economics, 38, 165-172.

Jeanjean, T., \& Stolowy, H. (2008). Do Accounting Standards Matter? An Exploratory Analysis of Earnings Management Before and After IFRS Adoption. Journal of Accounting and Public Policy, 27(6), 480-494. http://dx.doi.org/10.1016/j.jaccpubpol.2008.09.008

Jensen, M. (2005). Agency costs of overvalued equity. Financial Management, 34, 5-19. http://dx.doi.org/10.1111/j.1755-053X.2005.tb00090.x

Jones, J. (1991). Earnings management during import relief investigations. Journal of Accounting Research, 29(2), 193-228. http://dx.doi.org/10.2307/2491047

Kanagaretnam, K., Gerald, J. L., \& Yang, D. H. (2004). Joint tests of signaling and income smoothing through bank loan loss provisions. Contemporary Accounting Research, 21(4), 843-884. http://dx.doi.org/10.1506/UDWQ-R7B1-A684-9ECR

Kang, S. H., \& Sivaramakrishnan, K. (1995). Issues in testing earnings management and an instrumental variable approach. Journal of Accounting Research, 3(2), 353-367. http://dx.doi.org/10.2307/2491492

Kim, K., \& Schroeder, D. (1990). Analysts' use of managerial bonus incentives in forecasting earnings. Journal of Accounting and Economics, 13(1), 3-23. http://dx.doi.org/10.1016/0165-4101(90)90065-C

Kothari, S. P. (2001). Capital markets research in accounting. Journal of Accounting and Economics, 31(1-3), 105-231. http://dx.doi.org/10.1016/S0165-4101(01)00030-1

Kothari, S. P., Leone, A. J., \& Wasley, C. E. (2005). Performance matched discretionary accrual measures. Journal of Accouning and Economics, 39(1), 163-197. http://dx.doi.org/10.1016/j.jacceco.2004.11.002

Kothari, S. P., Lewallen, J., \& Warmen, J. B. (2003). Stock returns, aggregate earnings surprises and behavioural finance. MIT Sloan Working paper no 4284-03 Simon School of Business Working paper no 
FR03-05.

Krishnan, G. V. (2003). Audit quality and the pricing of discretionary accruals. Auditing: A Journal of Practice and Theory, 22(1), 109-126. http://dx.doi.org/10.2308/aud.2003.22.1.109

Laporta, R., Lopez-de-Silanes, F. A. S., \& Vishny, R. W. (2002). Investor protection and corporate valuation. Journal of Finance, 58(3), 1147-1170. http://dx.doi.org/10.1111/1540-6261.00457

Larson, E. A., \& Bogstrand, O. (2012). Have IFRS contributed to increase value Relevance. The Scandinavian Evidence. Lambert Academic Publishing, Publised on: 2012-11-17. Number of pages 52.

Leuz, C., \& Wysocki, P. (2008). Economic Consequences of Disclosure Regulation: A Review of Literature and Suggestions for Future Research. Working Paper, MIT.

Leuz, C., Nanda, D., \& Wysocko, D. P. (2003). Earnings Management and Investor Protection: An International $\begin{array}{lllll}\text { Comparisaon. Journal of Financial } & \text { Economics, } & \text { 69, }\end{array}$ http://dx.doi.org/10.1016/S0304-405X(03)00121-1

Li, S. (2010). Does Mandatory Adoption of International Financial Reporting Standards in the European Union reduce the cost of equity Capital? The Accounting Review, 85(2), 607-636. http://dx.doi.org/10.2308/accr.2010.85.2.607

Louis, H., \& Robinson, D. (2005). Do managers credibly use accruals to signal private information? Evidence from the pricing of discretionary accruals around stock splits. Journal of Accounting and Economics, 39(2), 361-380. http://dx.doi.org/10.1016/j.jacceco.2004.07.004

McNichols, M., \& Wilson, P. (1988). Evidence of Earnings Management from the provision for Bad debts. Journal of Accounting Research, 26(3), 1-31. http://dx.doi.org/10.2307/2491176

Meulen, S. V., Gaeremynck, A., \& Willekens, M. (2007). Attribute differences between U.S. GAAP and IFRS earnings: An exploratory study. The International Journal of Accounting, 42(2), 123-142. http://dx.doi.org/10.1016/j.intacc.2007.04.001

Nafti, O., Boumediene, E., \& Boumediene, S. L. (2013). IAS-IFRS adoption impact on accounting information: The case of France. Journal of Modern Accounting and Auditing, 9(3), 321-334.

Nelson, M. W., Elliott, J. A., \& Tarpley, R. L. (2002). Evidence from Auditors about Managers' and Auditors' Earnings Management Decisions. The Accounting Review, 77, 175-202. http://dx.doi.org/10.2308/accr.2002.77.s-1.175

Peluci-Grecco, M., Gero, C., Grecco, G., \& Lima, J. (2014). The effect of IFRS on earnings management in Brazilian non-financial public companies. Emerging Markets Review, 21, 42-66. http://dx.doi.org/10.1016/j.ememar.2014.07.001

Raffournier, B. (2007). Les oppositions françaises à l'adoption des IFRS: Examen critique \& tentative d'explication. Comptabilité-Contrôle-Audit, 21-41. http://dx.doi.org/10.3917/cca.133.0021

Revsine, L., Collins, D. W., \& Johnson, W. B. (2005). Financial reporting and analysis (3rd ed.). Upper Saddle River, NJ: Pearson Prentice Hall.

Smith, C. W., \& Warner, J. B. (1979). On financial contracting: An analysis of bond covenants. Journal of Financial Economics, 117-161. http://dx.doi.org/10.1016/0304-405X(79)90011-4

Soderstrom, N., \& Sun, K. (2007). IFRS adoption and accounting quality: A review. European Accounting Review, 16(4), 675-702. http://dx.doi.org/10.1080/09638180701706732

Subramanyam, K. (1996). The Pricing of Discretionary Accruals. Journal of Accounting and Economics, 22(1/3), 249-281. http://dx.doi.org/10.1016/S0165-4101(96)00434-X

Sweeney, A. (1994). Debt covenant violations and managers' accounting responses. Journal of Accounting and Economics, 17(3), 281-308. http://dx.doi.org/10.1016/0165-4101(94)90030-2

Teoh, S. H., Welch, I., \& Wong, T. J. (1998). Earnings management and the underperformance of seasoned equity offerings. Journal of Financial Economics, http://dx.doi.org/10.1016/S0304-405X(98)00032-4

Watts, R. L. (1977). Corporate financial statements, a product of the market and political processes. Australian Journal of Management, 53-75. http://dx.doi.org/10.1177/031289627700200104

Watts, R., \& Zimmerman, J. (1990). Positive accounting theory: A ten year perspective. The Accounting Review, 
65(1), 131-156.

Xie, H, (2001). The mispricing of accruals. The Accounting Review, 76, 357-373. http://dx.doi.org/10.2308/accr.2001.76.3.357

Zeff, S. A. (1998). Recent trends in accounting education and research in the USA: Some implications for UK $\begin{array}{lllll}\text { academics. } & \text { The } & \text { British } & \text { Accounting }\end{array}$ http://dx.doi.org/10.1016/0890-8389(89)90194-7

Zeghal, D., \& Mhedhbi, K. (2012). An analysis of the factors affecting the adoption of international accounting standards by developing countries. International Journal of Accounting and Information Management, 20(3), 220-237. http://dx.doi.org/10.1108/18347641211245100

\section{Note}

Note 1. Switzerland, Germany and Austria are the European countries where there is the highest proportion of companies applying IFRS early. Indeed, since 1998 the application of these standards has been authorized in Germany and Austria. As regards Switzerland, Dumontier and Raffourrnier (1998) showed that in a sample of 133 firms, 52 of them using IFRS.

\section{Copyrights}

Copyright for this article is retained by the author(s), with first publication rights granted to the journal.

This is an open-access article distributed under the terms and conditions of the Creative Commons Attribution license (http://creativecommons.org/licenses/by/3.0/). 